E. Leynaud: Organisation politique des Azandé.

A. Venciana: Notes sur les Bwiti.

G. Tardits: Les mythes, les institutions et les coutumes des Dogon.

Bibliographie des problèmes politiques actuels.

Communication de G. Balandier

\title{
The Advancement of African Women in the Belgian Congor
}

THE advancement of women in the Belgian Congo and Ruanda-Urundi was the subject discussed at the I 2th session of the Congrès Colonial National held in Brussels 23 and 24 November I956. The Congress received reports from four Commissions each of which was concerned with one of the following aspects of the problem: The legal status of African women; social welfare and assistance; education; the role of European women in the Congo. M. Paul Coppens, Secretary-General of the permanent committee of the Congrès Colonial National, summarized the reports and resolutions presented by the Commissions. Before the session, questionnaires had been circulated in the Colony, and the 62 answers received from a wide variety of sources, African as well as European, had provided material on which the reports of the Commissions were based.

A review of the status of women in the traditional African society led to the conclusion that indigenous law and custom in fact protected women, especially as wives and mothers, although denying them full legal status in theory. Rapidly changing economic and social conditions today were, however, undermining the traditional structure with consequent repercussions on the status of women. These were, of course, most acutely felt in urban centres and here the disparity between the stages of development reached by men and by women was most clearly evident. The problem was whether the traditional structure could be adapted to the needs of the future and to the women of the future. Welfare and educational facilities needed to be developed and multiplied and the active co-operation of educated Africans must be secured. There was need for many more schools for girls, primary and post-primary as well as vocational and professional, together with facilities for further training in Belgium.

It was suggested that European women living in the Congo, whether exercising a profession or accompanying their husbands, should receive some training and preparation for life in the Colony, should study one or other of the African languages and be encouraged to play their part in working for the common welfare.

\section{Missionary Conference on Literature in the Congo}

Tris conference, the last of six sponsored by the Conseil Protestant du Congo and the Evangelical Literature Organization and organized by Mr. Paul Stough of the Africa Inland Mission, met in Léopoldville in October 1956. Mr. Stough was assisted by the executive secretary of ELO, the Rev. Harold Street, and the International Committee for Christian Literature in Africa was represented by its London secretary, the Rev. Claude de Mestral. Language-area conferences were held as follows: Kikongo (Kikwit), Lingala (Bolenge), Congo-Swahili (Ruanguba), Bangala (Gombari), Kinyaruanda (Usumbura).

In proposing the resolution for the formation of a colony-wide committee, Mr. R. B. Anderson of the Methodist Evangelical Union suggested that it should be formed from the literature committees of local missions and from the area fellowships which had grown out of these. The function of such a committee would be to further the interchange of manuscripts between areas, to supervise the French literature programme, and to dispense neces-

I A lengthy report of the Congress, with numerous illustrations, was published in Belgique d'Outremer, Janvier 1957 . 
sary information to the whole of the Congo. The resolution recommended that the committee should be composed of the secretaries of the regional committees together with an appointed representative of the CPC. It was also recommended that the central committee should meet at least once annually.

One of the subjects discussed by the committees was the encouragement of original writing, preferably by Africans, and it was felt that wherever possible literature should be prepared on this basis, secondly by adaptations, and only as a last resort by translations. Other matters discussed were Mission presses, colportage work, and the desirability of increasing the circulation of the vernacular journals. Papers were also read on correspondence courses, tracts, bookshops, book clubs, planning a literature programme, and literature available and needed.

\section{Vernacular News-Sheets in the Belgian Congo}

THE publication of a news-sheet at Gandadjika in the Kasai marked the beginning of a movement to provide news and reading matter in the vernacular, and other areas are now following this example. The papers ate simple, generally consisting of a few stencilled pages and containing an editorial, one or more articles of general interest, an article on the history of the area, and news about sport and other events in the neighbourhood. The editorial board is composed entirely of Congolais, the chief of the territory combining his usual role with that of guide and adviser. In some territories correspondents for each native area (circonscription indigène) send in their local news. The language is generally the local vernacular, though some articles are written in French. Some news-sheets are published simultaneously in French and in the vernacular. Donations from the native area administration provide the initial finance for these publications, one of which may be started for a comparatively small sum, averaging little more than 36.000 francs. Once started, the paper depends on subscriptions and advertisements.

\section{Elisabethville University}

THE Government University at Élisabethville, Belgian Congo, was officially opened on Sunday, $1 \mathrm{r}$ November 1956, in the presence of the Minister of Colonies and professors from the four universities of Belgium. Letters of greeting were read from these as well as from the University of Lovanium (Léopoldville) whose Rector was present. The Rector of the new university outlined the reasons for its foundation and the hopes for its future; he welcomed the 42 African and European students who formed the first student body. The scholastic standard for entrance to the two Congo universities, and the level of studies pursued, will be the same as in the universities of Belgium.

\section{La sixieme Conférence des Africanistes de l'Ouest}

La sixième Conférence des Africanistes de l'Ouest s'est tenue à l'île de Sao Tomé du 21 au 28 août 1956 et a été consacrée à la fois à des séances de travail et à des excursions.

Le mérite de l'organisation revenait au Gouvernement portugais et notamment au Professeur A. Mendès Corrêa, Directeur de l'Institut supérieur des Études d'Outre-Mer de Lisbonne et membre du Comité permanent des conférences internationales des Africanistes de l'Ouest (C.I.A.O.). La session était placée sous l'égide de la Commission de Coopération technique en Afrique au sud du Sahara (C.C.T.A.) représentée à Sao Tomé par son secrétaire-général, M. Paul-Marc Henry.

Une quarantaine de congressistes, la plupart portugais, participaient à la conférence qui a été divisée en trois sections: la section physique, la section biologique et la section humaine. 